\title{
Admission predictors of mortality in Geriatrics intensive care
}

\author{
Mahmoud A. Refaee, MD ${ }^{\mathbf{1}}$, and Doha Rasheedy, MD ${ }^{\mathbf{1}}$. \\ 1 Lecturer of Geriatrics; Geriatrics and Gerontology Department; Faculty of \\ Medicine, Ain shams university, Cairo, Egypt.
}

Background: Elderly patients are a significant and increasing proportion of ICU patients. With advancing age, the comorbidities critically ill elderly patients have substantial mortality. The early recognition of patients at high risk of mortality is needed to plan care in advance and to control healthcare costs.

Aim: To find out the admission clinical and laboratory predictors of mortality in critically ill elderly admitted to ICU.

Method: A prospective study was performed in Geriatric ICU in Ain Shams University Hospitals including 90 critically ill elderly patients admitted for 24 hours or more. Each patient was subjected to on admission clinical assessment, in addition to laboratory investigations including; measurement of serum levels of Blood urea Nitrogen, Creatinine, Sodium, Potassium, Calcium, Phosphorus, Magnesium, Zinc, Bilirubin, Complete blood count (CBC), CRP and arterial blood gases.

Results: Mortality accounted for $39 \%$ of patient's outcome. Advanced age was significantly associated with increased mortality $(\mathrm{p}=0.03)$

The acute stroke as a cause of admission was found to be associated with increased mortality $(\mathrm{P}=0.00)$. Length of ICU stay and the use of mechanical ventilation significantly increased mortality $(\mathrm{P}=0.01, \mathrm{P}=0.000)$ respectively.

Tachycardia, tachypnea and deep coma were also found to be associated with increased mortality $(\mathrm{P}=0.003,0.02,0.000)$ respectively. Hematocrit, bicarbonate, and sodium levels were significantly lower among the non survivors.

Conclusions: The most important factors independently associated with the high risk of mortality among elderly admitted in ICU are; advanced age, impaired level of consciousness, need for mechanical ventilation, low serum sodium and bicarbonate levels. Early management of hyponatremia and metabolic acidosis is substantial for improving outcome in geriatric ICU.

Keywords: intensive care units, ICU mortality, elderly, hyponatemia, serum bicarbonate.

\section{Introduction:}

The elderly population is growing in Egypt, like in many other countries, There were 4,400,000 persons aged 60 and over representing $6.9 \%$ of the total population in 2006. The expected percentage of older people may reach $8.9 \%$ in 2016 and $10.9 \%$ in $2026^{(1)}$.

Life expectancy for Egyptian females was 63.5 years in 1986 increased to 73.6 years in 2006. While, Life expectancy in males was 60.5 years in 1986 and increased to 69.2 years in $2006^{(1)}$
This rapid rise in the elderly population worldwide is paralleled by increase in utilization of health care resources (2). Moreover, elderly will need ICU admission more frequently and their management will be more challenging.

Data showed that $55 \%$ of all ICU beddays are occupied by patients aged $\geq$ 65 years ${ }^{(3)}$.

Old age is associated with increased mortality in critically ill patients (4). However, age alone wasn't a strong predictor for mortality. There is 
evidence suggesting that acute physiological impairment and associated comorbidities were predictors of mortality after adjustment of age ${ }^{(5,6)}$.

the current study was designed to study predictors for mortality in critically ill elderly patients at the time of admission, the early recognition of patients at high risk of mortality is needed to plan care in advance and to control healthcare costs.

\section{Methods:}

\section{Study design:}

A prospective single center study was conducted to assess the relationship between different clinical and laboratory parameters and clinical outcome for ICU elderly patients. 90 consecutively admitted patients were included in the study. All patients were 60 years and over. Patients with ICU stay of less than 24 hours were excluded. The patients were divided into survival group (those who were discharged from the ICU after improvement) and non-survival group (those who died in the ICU). The study was carried out in the ICU of the Geriatrics and Gerontology Department at Ain Shams University Hospital in Cairo Egypt.

\section{Laboratory assessment:}

Blood samples were collected on admission to ICU for estimation of serum levels of Blood urea Nitrogen, Creatinine, Sodium, Potassium, Calcium, Phosphorus magnesium, Zinc, and bilirubin. Most of these laboratory investigations are widely used in intensive care settings; moreover, measuring serum Zinc, Copper and Bilirubin levels gained recent attention as predictors of mortality in elderly population.

Complete blood count (CBC), CRP and arterial blood gases were measured also on admission.
Laboratory measures were all performed in Ain Shams University Central Laboratories.

\section{Ethical considerations}

The study methodology was reviewed and approved by the Research Review Board of the Geriatrics and Gerontology Department, Faculty of medicine, Ain Shams University.

Statistical methods:

The collected data were coded, tabulated, revised and statistical analyzed using SPSS program (version 16). Quantitative variables were presented in the form of means and standard deviation. Qualitative variables were presented in form of frequency tables (number and percent).The comparison between quantitative variables was done using t-test. Comparison between qualitative variables was done using Pearson's Chi square test. Spearsman's correlation coefficient was used for non- parametric correlations. Multivariate logistic regression analysis was used to determine the independent predictors of ICU mortality. Variables that had a significant association with mortality to a value of $\mathrm{p}<0.05$ on univariate analysis were entered into a stepwise logistic regression analysis. Odds ratios (ORs) and $95 \%$ confidence intervals (CIs) were used to estimate the independent determinants of ICU mortality. P-values $<0.05$ were considered significant for all tests. Receiver operating characteristic (ROC) curves were constructed. The area under each ROC curve was calculated to assess the discriminatory ability of the assessed predictors to distinguish whether a patient would die or survive.

\section{Results:}

The study included 90 participants $48(53.3 \%)$ females and $42(46.7 \%)$ 
males. All of the participants were $\geq 60$ years old with mean age $68.57+7.4$ years (range 60-91 years).the leading cause of admission was neurological emergency in 30 cases(33.3\%)(acute stroke24(26.6\%), Intra cerebral hemorrhage 6(6.7\%)). While the second most common cause was Respiratory failure in 15 cases (16.7\%), followed by 10 cases $(11.11 \%)$ admitted with hepatic encephalopathy, 9 (10\%) cases admitted in shock state, $8(8.8 \%)$ cases had myocardial infarction, $8(8.8 \%)$ cases suffered from pneumonia, $4(4.4 \%)$ cases with rapid $\mathrm{AF}, 2($ $2.2 \%)$ cases with hypertensive crisis, 2 ( $2.2 \%$ ) cases with dehydration, and 2 $(2.2 \%)$ cases admitted due to viral encephalitis

Studying the relation between the cause of admission and mortality revealed that only acute stroke had statistically significant relation to mortality $(P=0.00)$ (table 1$)$.

Length of ICU stay and the use of mechanical ventilation were found to be associated increased mortality $(\mathrm{P}=$ $0.01, P=0.000$ ) respectively (table 2 ).

There was no significant relation between different co morbidities and mortality (table 2)

Up on studying the relation between clinical signs on admission and mortality: tachycardia, tachypnea and deep coma statistically were found to be associated with increased mortality $(\mathrm{P}=0.003,0.02,0.000)$ respectively (table 3)

The difference between the survivors and the non survivors regarding different laboratory measures were presented in (table 3). Hematocrit, bicarbonate, and sodium levels were significantly different between the two groups.
Table 1: The relation between the cause of admission and mortality

\begin{tabular}{|c|c|c|c|}
\hline $\begin{array}{l}\text { Cause of } \\
\text { admissio } \\
n\end{array}$ & $\begin{array}{l}\text { Survi } \\
\text { vors } \\
n=51\end{array}$ & $\begin{array}{l}\text { non } \\
\text { survivor } \\
\text { s } n=39\end{array}$ & $p$-value \\
\hline Stroke & $6(6.7$ & $18(20)$ & $0.00 *$ \\
\hline $\begin{array}{l}\text { Intracere } \\
\text { bral }\end{array}$ & $\begin{array}{l}4(4.4 \\
)\end{array}$ & $2(2.2)$ & 0.6 \\
\hline$\underset{\text { M.1 }}{\text { Myocard }}$ & $7(7.8$ & $1(1.1)$ & 0.06 \\
\hline $\begin{array}{l}\text { Hepatic } \\
\text { encephal }\end{array}$ & $\begin{array}{l}6(6.7 \\
)\end{array}$ & $4(4.4)$ & 0.82 \\
\hline Respirat & $10(1$ & $5(5.6)$ & 0.3 \\
\hline $\begin{array}{l}\text { Uncontr } \\
\text { olled }\end{array}$ & $\begin{array}{l}2(2.2 \\
)\end{array}$ & 0 & 0.2 \\
\hline Pneumo & $4(4.4$ & $4(4.4)$ & 0.6 \\
\hline $\begin{array}{l}\text { Viral } \\
\text { encephal }\end{array}$ & $\begin{array}{l}2(2.2 \\
)\end{array}$ & 0 & 0.2 \\
\hline Dehydrat & $2(2.2$ & 0 & 0.2 \\
\hline Rapid & $4(4.4$ & 0 & 0.074 \\
\hline Shock & $5(5.6$ & $4(4.4)$ & 0.6 \\
\hline
\end{tabular}

The results of Spearman's correlation coefficient and multivariate analysis are shown in (table 4,5$)$ respectively.

Serum sodium and bicarbonate levels are considered routine inexpensive investigations in all critical care facilities.

The Roc curve analysis demonstrated that the probabilities of predicting mortality by measuring serum sodium and bicarbonate on admission were $76.1 \%$ and $65 \%$ respectively (figure 1 )

Serum Bicarbonate level of $15 \mathrm{mg} / \mathrm{dl}$ had $94.1 \%$ sensitivity and $71.8 \%$ specificity to predict mortality in critically ill elderly, whereas, serum Sodium level of $120 \mathrm{mg} / \mathrm{dl}$ had $96.1 \%$ 
sensitivity and $79.5 \%$ specificity to predict mortality.

Table 2: characteristic of participants:

\begin{tabular}{|c|c|c|c|c|}
\hline & & Survivors & Non Survivors & $p$-value \\
\hline \multicolumn{2}{|l|}{ age Mean(SD) } & $67.7(6.7)$ & $70.6(7.8)$ & $0.04 *$ \\
\hline \multicolumn{2}{|c|}{ Body mass index Mean(SD) } & $22.4(4.6)$ & $23.5(4.9)$ & 0.26 \\
\hline \multicolumn{2}{|c|}{ Length of stay Mean(SD) } & $4.1(1.5)$ & $9.1(4.6)$ & $0.01 *$ \\
\hline \multicolumn{2}{|c|}{ APACHEII score Mean $(S D)$} & $18(7.07)$ & 21.7(7.07) & $0.002 *$ \\
\hline \multirow[t]{2}{*}{ Gender } & Male & $25(27.8)$ & 17(18.9) & \multirow[t]{2}{*}{0.6} \\
\hline & Female & $26(28.9)$ & $22(24.4)$ & \\
\hline \multirow{2}{*}{$\begin{array}{l}\text { Use of mechanical } \\
\text { ventilation }\end{array}$} & Yes & $6(6.7)$ & $24(26.7)$ & \multirow[t]{2}{*}{$0.000 *$} \\
\hline & No & $45(50)$ & $15(16.7)$ & \\
\hline \multicolumn{2}{|l|}{ Renal disease $n(\%)$} & $19(21.1)$ & $19(21.1)$ & 0.27 \\
\hline \multicolumn{2}{|l|}{ Liver cirrhosis $n(\%)$} & $6(6.7)$ & $6(6.7)$ & 0.61 \\
\hline \multicolumn{2}{|l|}{ Diabetes $n(\%)$} & $23(25.6)$ & $22(24.4)$ & 0.28 \\
\hline \multicolumn{2}{|c|}{ Respiratory disorders $n(\%)$} & $12(13.3)$ & $8(8.9)$ & 0.73 \\
\hline \multicolumn{2}{|l|}{ Hypertension $n(\%)$} & $33(36.7)$ & $21(23.3)$ & 0.29 \\
\hline
\end{tabular}

\section{Discussion:}

The goal of the current study was to evaluate the early predictors of mortality in elderly patients admitted to ICU.

Among the admitted subjects, (43.3\%) patients died and the rest survived to ICU discharge. There was a statistically significant difference between survivors and non survivors as regards their age. This agrees with previous studies $(7,8)$ reported that advanced age was a significant independent risk factor for mortality. However, the advanced age alone shouldn't preclude optimal ICU treatment provided to elderly patients.

Data from the current study suggests that acute neurological insult was responsible for $22.2 \%$ of mortality in critically ill elderly patients followed by type II respiratory failure which accounted for $12.8 \%$ of the mortality.

The current study showed that mechanical ventilation was related to increased ICU mortality, $80 \%$ of mechanically ventilated patients died $(\mathrm{p}=0.000)$, this was supported by previous studies ${ }^{(9)}$.

The survivors group had a significantly shorter ICU stay than did nonsurvivors $(p=0.01)$.This finding agree with Mayr et al., (10) who found that ICU non-survivors did not die early in the course of the disease but primarily in the period of prolonged critical illness. This proves the effects attributed to chronic critical illness. 
Table 3: relation between on admission clinical signs, Laboratory results and outcome

\begin{tabular}{|c|c|c|c|}
\hline & Survivors & Non & $p$ \\
\hline Temperature ${ }^{\circ}$ C Mean(SD) & $37.7(0.78)$ & $37.8(0.8)$ & 0.41 \\
\hline Pulse Beats/min Mean(SD) & 91.2(13.7) & $104.5(16.3)$ & $0.003 *$ \\
\hline Respiratory rate breaths/min & $24.45(8)$ & $32.67(8.7)$ & $0.02 *$ \\
\hline Mean Arterial pressure & $85.6(19.8)$ & $81.3(18.4)$ & 0.75 \\
\hline Glasgow coma score & $11.9(2.6)$ & $8.7(3.3)$ & $0.000 *$ \\
\hline$P H$ & $7.3(0.11)$ & $7.4(0.11)$ & 0.2 \\
\hline $\mathrm{PaO} 2$ & $67(20.6)$ & $65.5(23.5)$ & 0.6 \\
\hline Bicarbonate $(m g / d l)$ & $21.6(6.2)$ & $18.9(5.9)$ & $0.02 *$ \\
\hline Creatinine ( $m g / d l)$ & $2.04(1.76)$ & $2.46(2.1)$ & 0.3 \\
\hline WBCs $(1000 / u L)$ & $12.3(6)$ & $15(6.7)$ & 0.06 \\
\hline Hemoglobin $(g / d l)$ & $11.9(0.8)$ & $10.4(0.7)$ & 0.1 \\
\hline Hematocrit \% & $36.4(9)$ & $33.2(6.5)$ & $0.05 *$ \\
\hline platelets $(1000 / u L)$ & $240(18.7)$ & $236.8(22.6)$ & 0.9 \\
\hline$N a(m g / d l)$ & $135.7(10.4)$ & $127.3(7.4)$ & $0.000 *$ \\
\hline$K(m g / d l)$ & $4.8(4.1)$ & $3.9(1)$ & 0.19 \\
\hline $\mathrm{Ca}(m g / d l)$ & $8.2(0.5)$ & $8.4(0.5)$ & 0.08 \\
\hline PO4 (mg/dl) & $3.3(0.57)$ & $3.3(0.56)$ & 0.8 \\
\hline$M g(m g / d l)$ & $2.2(0.29)$ & $2.3(0.2)$ & 0.9 \\
\hline $\mathrm{Zn}(m g / d l)$ & $82.7(11.4)$ & 79.1(9) & 0.1 \\
\hline$C u(m g / d l)$ & $97.67(15.2)$ & 91.9(12.97) & 0.062 \\
\hline bilirubin $(m g / d l)$ & $0.6(0.8)$ & $0.5(0.2)$ & 0.3 \\
\hline
\end{tabular}

In the current study $24(61.5 \%)$ of non survivors had hypornatremia, and serum sodium level on admission negatively correlated with ICU mortality. With multivariate analysis serum sodium level on admission was independent predictor for ICU mortality. This is supported by previous studies ${ }^{(11,12) \text {. }}$

Whereas, only $4(4.4 \%)$ were found to have hypernatremia. This support previous data that hypernatremia was less common than hyponatremia ${ }^{(13)}$ Despite that the serum levels of different electrolytes (calcium, phosphorus, magnesium, zinc and copper) attracted many researchers to investigate their prognostic value in the ICU settings. Most of the studies measured the occurrence of electrolyte imbalance during the course of critical illness not the baseline levels on admission to ICU.

In Our study there were no significant difference between survivors and non survivors regarding on admission levels of calcium, phosphorus, magnesium, zinc and copper. 
Egi et al., 2011 reported that ionized calcium concentration had no independent association with hospital or intensive care unit mortality except for extreme abnormalities of ionized calcium concentrations ${ }^{(14) .}$

Safavi and Honarmand, $2007 \quad$ (15), reported that hypomagnesemia during ICU stay was associated with poor prognosis. There was significant difference between those with normal and low magnesium levels in mortality rate (55\% vs. 35\%), the length of ICU $(9.16+/-0.53$ vs. $5.71+/-0.55)$ stay.

Table 4: correlation between different predictors and mortality

\begin{tabular}{lll}
\hline & $R$ & $P$ \\
\hline age & 0.225 & $0.033 *$ \\
$\begin{array}{l}\text { Respiratory rate } \\
\text { (breaths/min) } \\
\text { pulse (Beats/min) }\end{array}$ & 0.269 & $0.01 *$ \\
\hline $\begin{array}{l}\text { Length of stay } \\
\text { (davs) }\end{array}$ & 0.309 & $0.003 *$ \\
$\begin{array}{l}\text { Use of mechanical } \\
\text { ventilation }\end{array}$ & 0.485 & $0.000 *$ \\
$\begin{array}{l}\text { Glasgow coma } \\
\text { score }\end{array}$ & - & $0.02 *$ \\
$\begin{array}{l}\text { Serum bicarbonate } \\
\text { (mo/dl) }\end{array}$ & - & $0.000 *$ \\
$\begin{array}{l}\text { Serum Sodium } \\
\text { (mo/dl) }\end{array}$ & 0.258 & $0.014 *$ \\
$\begin{array}{l}\text { Hematocrit \% } \\
\text { CRP }\end{array}$ & - & 0.449 \\
\hline
\end{tabular}

However, Escuela et al., $2005^{(16)}$ study reported that the serum $\mathrm{Mg}$ concentrations were similar in both deceased and alive subjects. They found no association between mortality and hypo- or hypermagnesemia determined upon admission, results similar to the current study.

There was no significant difference found between survivors and non survivors regarding Serum zinc and copper levels. This agrees with Cander et al., $2010^{(17)}$ who reported that serum zinc and copper levels had no significant relationship with mortality or length of stay in the ICU.

Table 5: multivariate logistic regression analysis:

\begin{tabular}{|c|c|c|c|c|}
\hline Variable & $\beta$ & $O R$ & $\begin{array}{l}95 \% \\
C I\end{array}$ & $\begin{array}{l}p- \\
\text { valu }\end{array}$ \\
\hline age & $-\overline{0.14}$ & $\begin{array}{l}0.8 \\
66\end{array}$ & $\begin{array}{l}0.76 \\
4-\end{array}$ & $\begin{array}{l}0.02 \\
5 *\end{array}$ \\
\hline $\begin{array}{l}\text { Respirato } \\
\text { ry rate }\end{array}$ & - & $\begin{array}{l}0.9 \\
78\end{array}$ & 0.88 & $\begin{array}{l}0.67 \\
6\end{array}$ \\
\hline $\begin{array}{l}\text { pulse } \\
\text { (Beats/mi }\end{array}$ & & $\begin{array}{l}1.0 \\
26\end{array}$ & $\begin{array}{l}0.98 \\
7-\end{array}$ & $\begin{array}{l}0.19 \\
3\end{array}$ \\
\hline $\begin{array}{l}\text { Length of } \\
\text { stay }\end{array}$ & & $\begin{array}{l}1.1 \\
93\end{array}$ & $\begin{array}{l}0.93 \\
8-\end{array}$ & $\begin{array}{l}0.15 \\
0\end{array}$ \\
\hline $\begin{array}{l}\text { Use of } \\
\text { mechanic }\end{array}$ & - & $\begin{array}{l}0.0 \\
48\end{array}$ & $\begin{array}{l}0.00 \\
6-\end{array}$ & $\begin{array}{l}0.00 \\
5 *\end{array}$ \\
\hline $\begin{array}{l}\text { Glasgow } \\
\text { coma }\end{array}$ & - & & $\begin{array}{l}0.63 \\
5-\end{array}$ & $\begin{array}{l}0.03 \\
9 *\end{array}$ \\
\hline $\begin{array}{l}\text { Serum } \\
\text { bicarbona }\end{array}$ & - & $\begin{array}{l}0.8 \\
47\end{array}$ & & $\begin{array}{l}0.00 \\
5^{*}\end{array}$ \\
\hline $\begin{array}{l}\text { Serum } \\
\text { Sodium }\end{array}$ & - & & & $\begin{array}{l}0.00 \\
7 *\end{array}$ \\
\hline \multicolumn{5}{|c|}{$\begin{array}{l}\text { Fu and Zang, } 2012^{(18)} \text { reported that the } \\
\text { serum phosphate level had a prognostic } \\
\text { value as a predictor for mortality. Like } \\
\text { other studies, they measured the } \\
\text { hypophosphatemia that developed } \\
\text { during the course of the illness not the } \\
\text { serum level during admission. }\end{array}$} \\
\hline
\end{tabular}

Figure 1: ROC curve for detection of mortality by serum Sodium and bicarbonate on admission

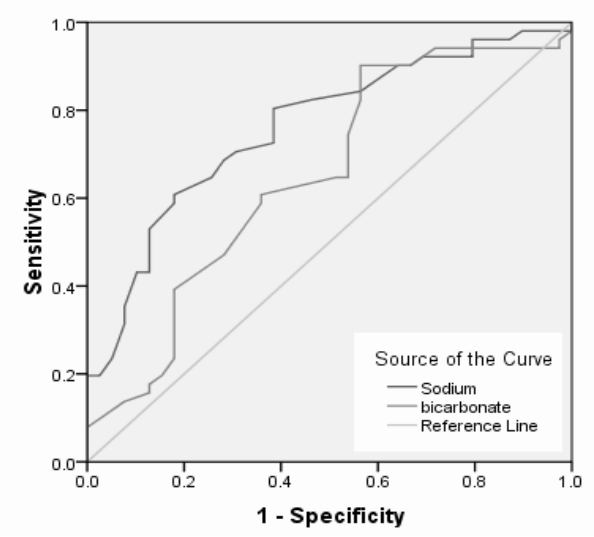


Area under the curve for sodium

$0.76195 \%$ CI (0.662-0.86), while

the area under the curve for

bicarbonate $0.65095 \%$ CI (0.5340.767)

As in other studies ${ }^{(19,20)}$, the APACHE II score in the current study was accurate to predict mortality in the critically ill elderly subjects. In the current study the mean APATCHE II score was higher among the nonsurvival group with high statistical significant difference.

Although the current study is a singlecenter study, but it detected the early predictors for mortality in elderly patients admitted to ICU. However, it lacks the analysis of the factors that can influence patient outcome during the course of an ICU stay, future studies for evaluation of changes in patient status over time is needed.

\section{Conclusions}

Elderly patients with acute neurological insult had a higher mortality when compared to other emergency causes of ICU admission. The advanced age, Mechanical ventilation, low serum sodium and bicarbonate levels on admission are independent predictors of mortality in elderly critically ill patients. Early management of hyponatremia and metabolic acidosis is substantial for improving outcome in geriatric ICU.

\section{Acknowledgments:}

The authors acknowledge to the central laboratories in Ain Shams University.

\section{Funding:}

This research received no specific grant from any funding agency in the public, commercial, or not-for-profit sectors

\section{Disclosure:}

The author(s) declared no conflicts of interest with respect to the authorship and/or publication of this article.

\section{References:}

1. The Central Agency for Public Mobilization and Statistics (CAPMAS): the thirteenth Egyptian census, 2006.

2. Boumendil A, and Guidet B: Elderly patients and intensive care medicine. Intensive Care Med 2006, 32:965-967.

3. Angus DC, Barnato AE, LindeZwirble WT et al. Use of intensive care at the end of life in the United States: an epidemiologic study. Crit Care Med 2004, 32:638-643.

4. Vosylius S, Sipylaite J, and Ivaskevicius J: Determinants of outcome in elderly patients admitted to the intensive care unit. Age Ageing 2005, 34:157-162.

5. Bo M, Massaia M, Raspo S, et al. Predictive factors of in-hospital mortality in older patients admitted to a medical intensive care unit. J Am Geriatr Soc 2003, 51:529-533.

6. Rosenthal GE, Kaboli PJ, Barnett MJ, et al. Age and the risk of inhospital death: insights from a multihospital study of intensive care patients. J Am Geriatr Soc 2002, 50:1205-1212.

7. Fuchs L, Chronaki CE, Park S, et al. ICU admission characteristics and mortality rates among elderly and very elderly patients. Intensive Care Med. 2012; 38(10):1654-1661.

8. Yu W, Ash AS, Levinsky NG et al. Intensive Care Unit Use and Mortality in the Elderly. J Gen Intern Med >2000; 15: 97-102.

9. Gajic O, Afessa B, Thompson BT, et al., Prediction of death and prolonged mechanical ventilation in acute lung injury. Critical Care. 2007; 11 (3): 53.

10. Mayr VD, Dünser MW, Greil V, et al. Causes of death and 


\section{Egyptian Journal of Geriatrics and Gerontology \\ March 2014 Volume 1(1)}

determinants of outcome in critically ill patients. Critical Care.2006; 10 (6): 154.

11. Chowdhury R, Samanta T, Pan K, et al. Can hyponatremia predict

12. Stelfox HT, Ahmed SB, Khandwala F, et al. The epidemiology of intensive care unit-acquired hyponatraemia and hypernatraemia in medicalsurgical intensive care units. Critical Care, 2008; 12, R162.

13. Snyder NA, Feigal DW, and Arieff AI. Hypernatremia in elderly patients. A heterogeneous, morbid, and iatrogenic entity. Ann Intern Med. 1987; 107:309-319.

14. Egi M, Kim I, Nichol A, et al. Ionized calcium concentration and outcome in critical illness. Crit Care Med. 2011; 39(2):314-21.

15. Safavi M, and Honarmand A. Admission hypomagnesemia-impact on mortality or morbidity in critically ill patients. Middle East J Anesthesiol. 2007;19(3):645-660

16. Escuela MP, Guerra M, Añón JM et al. Total and ionized serum magnesium in critically ill patients. Intensive Care Med 2005; 31 (1): 151- 156.

17. Cander B, Dundar D, Gul M, et al. Prognostic value of serum zinc levels in critically ill patients. Crit Care. 2010; 14(Suppl 1): P593.

18. $\mathrm{Fu} \mathrm{JH,} \mathrm{and} \mathrm{Zang} \mathrm{B.} \mathrm{The}$ occurrence of hypophosphatemia and its prognostic value in intensive care unit patients. Zhongguo Wei Zhong Bing Ji Jiu Yi Xue. 2012 ; 24(1):29-32.

19. Sakr, Y., Krauss, C., Amaral, A.C., et al., Comparison of the performance of SAPS II, SAPS 3, APACHEII, and their customized prognostic models in a surgical intensive care unit. British Journal of Anaesthesia, 2008: 101; 798803.

20. Mbongo CL, Monedero P, Guillen-Grima, F, et al., Performance of SAPS3, compared mortality in intensive care unit patientsa prospective study in a tertiary care hospital care hospital of Kolkata? IJMPS. 2013; 3(7): 26-30.

with APACHII and SOFA, to predict hospital mortality in a general ICU in Southern Europe. European Journal of Anaesthesiology.2009: 26; 940945. 